\title{
PHYSICOCHEMICAL AND MICROBIOLOGICAL STANDARDS OF HONEY PRODUCED BY GENUS MELIPONA
}

\author{
Ina Ramírez-Miranda' \\ David Betancur-Ancona² \\ Yolanda Moguel-Ordóñez ${ }^{3 *}$ \\ ${ }^{1}$ Posgrado Institucional de Ciencias Agropecuarias y Manejo de Recursos Naturales \\ Tropicales, UADY, Mérida, Yucatán, México \\ 2 Facultad de Ingeniería Química, UADY, Mérida, Yucatán, México \\ ${ }^{3}$ Campo Experimental Mocochá, CIRSE, INIFAP, Mocochá, Yucatán México \\ *correspondning author: moguel.yolanda@inifap.gob.mx \\ Received: 14 November 2020; accepted: 22 June 2021
}

\section{Abstract}

For thousands of years, honey from stingless bees, mainly from Melipona beecheii, has been recognized as part of traditional Mayan medicine in the Mesoamerican region. Currently Melipona honey is the subject of research due to its nutritional, therapeutic and commercial value. Studies have been conducted to characterize Melipona honey produced on Mexico's Yucatan Peninsula in, but the results have been limited. The low production and botanical-geographical origin of the honey increases the variability of the results and also the real number of Melipona beekeepers in the area is unknown so we are unable to conduct a statistically representative sampling and enough information to establish a generalization of the information. Therefore, we reviewed the published articles that describe the physicochemical and microbiological characteristics of the honey of some species of the genus Melipona. The information analyzed indicated that some of these characteristics are out of the specifications established by the standard that applies to Apis mellifera honey, without this meaning that it is of lesser quality and therefore. Because production and commercialization of this product is prospering, physicochemical and microbiological standards must be established to avoid adulteration and complications to public health, since this product is widely used for therapeutic purposes.

Keywords: honey, Melipona, microbiological criteria, physicochemical parameters

\section{INTRODUCTION}

The genus Melipona includes some forty known species of stingless honey bees (Michener, 2007). Due to their taxonomic classification they are located within the family Apidae, subfamily Apinae and the tribe Meliponini (Arnold et al., 2018a). Their natural distribution is from Mexico to Argentina (Michener, 2007). Originally their habitat is in tropical lowland forests, which depends on the cycles and a variety of forest resources (Villanueva et al., 2005). The geographic distribution of the Mexican honeybee can follow three patterns: wide tropical and subtropical distribution, distribution associated with tropical evergreen forest and endemisms (Ayala et al., 2013). Some researchers have presented information on the distribution of the species reported in southeastern Mexico, where it is possible to observe that the highest diversity of these bees (Arnold et al., 2018b).

Long before the arrival of the Spanish colonizers, the breeding of Melipona beecheii("xunaan-kab", "colel-kab", "pool-kab") (González, 2012) had been widely practiced by the Mayans of the Yucatan peninsula and been a culturally and economically important activity (Pat et al., 2018). The Mayans used honey as a sweetener, antibiotic and ingredient in "balché", a fermented drink of cultural importance that is still consumed today (Cortopassi et al., 2006).

Within Mayan traditional medicine, honey has been used to treat eye, ear, respiratory, digestive 
and skin problems (González \& Quezada, 2010), to clean the blood in women after childbirth, and a soothing balm for sleeping, among others (Vit et al., 2015). Currently, Melipona honey is considered a functional food that interferes with the body's functions in a specific and positive way, provides a physiological effect beyond its traditional nutritional value and contributes to the maintenance of health and well-being (Cauich et al., 2015).

According to the Codex Alimentarius (CXS 12, 1981), honey "is the natural sweet substance produced by honey bees from the nectar of plants or the secretions of living parts of plants or excretions of plant-sucking insects in the living parts of the plants, which the bees collect, transform by combining with their own specific substances, deposit, dehydrate, store and leave in the honeycomb to ripen and mature". This definition was adopted for the Mexican standards NMX (2006) and NOM (2018).

However, since current standards apply to A.mellifera honey, it is not appropriate to compare the quality of meliponid honey with the requirements and limits established in those standards, which is why Vit et al. (2004) proposed quality standards for the Melipona, Scaptotrigona and Trigona genera as a reference, provided that the corresponding standard did not exist (Fonte et al., 2013). However, Malaysia (Malaysia Standard, 2017) and Argentina (Official Gazette of the Republic of Argentina) have recently developed standards for the quality control of honey produced by Heterotrigona itama(Kelulut) and Tetragonisca fiebrigi, respectively. For this reason, the historical and cultural background of $M$. beecheii honey in the Yucatan Peninsula and the increased production, transforming and marketing of this product justify the development standardized regulations. In addition, and public health hazards would be reduced, fraud prevent and this product's the position on the market improved.

This manuscript summarises the information regarding the physicochemical parameters and microbial criteria from different Melipona species honeys, from books, review articles and research studies related to stingless bee honey and published from 2000 to date from which full access was obtained in servers such as Google Scholar, PubMed and ScienceDirect. Papers that did not mention the genus Melipona were excluded.

\section{Physicochemical characterization of honey}

Meliponini honeys have been characterized physicochemically with the same parameters applied for $A$. mellifera honeys. These parameters and quality criteria are specified for $A$. mellifera honey by such international regulatory standards as the Codex Alimentarius for honey and the European Honey Directive

Table 1.

Values minimum and maximum values of physicochemical parameters for honeys of the genus Melipona by the referenced authors

\begin{tabular}{ccc}
\hline Parameters & Min & Max \\
\hline Reducing sugars $(\mathrm{g} / 100 \mathrm{~g})$ & 34.8 & 82.1 \\
Fructose $(\mathrm{g} / 100 \mathrm{~g})$ & 29.2 & 59.2 \\
Glucose $(\mathrm{g} / 100 \mathrm{~g})$ & 21.8 & 45.7 \\
Sucrose $(\mathrm{g} / 100 \mathrm{~g})$ & 0.1 & 9.1 \\
Moisture $(\%)$ & 17.3 & 45.8 \\
pH & 2.8 & 6.6 \\
Free acidity (meq/kg) & 1.0 & 120.0 \\
Electrical conductivity $(\mu \mathrm{S} / \mathrm{cm})$ & 102.8 & 830.0 \\
Ash $(\%)$ & 0.01 & 0.6 \\
\hline
\end{tabular}


and reviewed by such organizations as the International Honey Commission (Bogdanov et al., 2015). However, different limits should be established for meliponini honeys, since the results of their physicochemical composition reported by various authors indicate values outside the limits established in the standards for $A$. mellifera honey. This does not mean that the meliponini honeys are of lower quality, but rather different from those of $A$. mellifera. In fact, the differences are not only with respect to $A$. mellifera honey, because even though numerous studies have highlighted the similar composition of honeys produced by different genera of stingless bees, differences between them have also been observed (Vit, 2008). These differences exist in honeys of the same genus Melipona; and Tab. 1 presents the minimum and maximum physicochemical parameters reported by the various authors cited in this review, observing a wide range among all the parameters.

\section{Sugars}

Sugars are mainly responsible for the physical characteristics and chemical behavior of honey. Sucrose content in honey is analyzed to identify any improper handling. High levels may indicate adulterations including the addition of such inexpensive sweeteners as cane sugar, early harvesting indicating that sucrose was not completely transformed into glucose and fructose or prolonged artificial feeding of bees with sucrose syrups (Tornuk et al., 2013). The enzymatic action splits sucrose into monosaccharide ranging from $65 \%$ to $80 \%$ of total soluble solids, with fructose (approximately $38.5 \%$ ) and glucose (approximately 31.0\%) being found in higher concentrations. The average ratio of fructose to glucose is 1.2:1, which depends considerably on the source of nectar from which the honey was made (Escuredo et al., 2014; Tornuk et al., 2013). Almeida et al. (2007), reported that from samples collected in Brazil's Amazon region the average values of fructose, glucose and sucrose were $31.91 \%$, $29.30 \%$ and $0.19 \%$ respectively for honeys produced by Melipona compressipes manaoense and Melipona seminigra merribae, and for honey by Melipona subnitida (Jandaira) the values were $29.21 \%, 21.76 \%$ and $4.86 \%$.

In 2017, the Malaysian Standards Department, the agency that regulates the sale and distribution of honey produced by stingless bees, published in its quality standards that good quality honey should have a concentration of fructose and glucose not exceeding $85 \mathrm{~g} / 100$ $\mathrm{g}$ of honey and not more than $7.5 \mathrm{~g}$ and $9.5 \mathrm{~g}$ of sucrose and maltose, respectively (Abd et al., 2017). With respect to $M$. beecheii honey produced in the province of Matanzas (Cuba), Fonte et al. (2013) indicated a percentage of 34.11, 29.30 and 6.54 for fructose, glucose and sucrose. Dardón \& Enríquez (2008) described in M. beecheii honey from Guatemala a concentration of reducing sugars of $68.77 \mathrm{~g} / 100 \mathrm{~g}$, very similar to what was detected, by Moo et al. (2015) with a range of 57.1 to $74.2 \mathrm{~g} / 100 \mathrm{~g}$ and an average of $67.7 \mathrm{~g} / 100 \mathrm{~g}$ for samples of the same species from the Yucatan Peninsula.

Oliveira et al. (2017) described how the concentration of reducing sugars for seven meliponas species from Brazil, M. alsilvai, M. q. anthidiodes, M. q. quadrifasciata, M. mandacaia, M. scutellaris, $M$. compressipes and $M$. subnitida, ranged between $34.83 \%$ and $78.95 \%$. The lowest level was for M. mandacaia (34.83 $\pm 1.2 \%)$, which was contrary to the average value of $74.82 \%$ for the same species reported by Alves et al. (2005). The mean value was $65.42 \%$ for $M$. mondury (Alves et al., 2018).

Souza et al. (2006) reported that the amount of reducing sugars tended to be higher in Melipona honey compared to other Meliponini, which was confirmed by Dardón \& Enríquez (2008). However, these results obtained show that most of the fructose plus glucose and sucrose concentrations are lower in relation to the honey produced by $A$. mellifera, which could be considered as immature and cause Melipona honey to ferment (Oliveira et al., 2017). As observed in Tab. 2, the concentration of reducing sugars varies, and in some cases the minimum amount was quantified as established by Codex Alimentarius for $A$. mellifera (60 g/100 g) (CXS $12,1981)$. Vit et al. (2004) suggested that the 
specification established in Codex for honey in relation to reducing sugars should decrease from $60 \mathrm{~g} / 100 \mathrm{~g}$ to not less than $50 \mathrm{~g} / 100 \mathrm{~g}$ and maximum $6 \mathrm{~g} / 100 \mathrm{~g}$ of sucrose for meliponas.
Moisture and water activity (Aw)

Water is the second largest component of honey. Its content varies from 15 to $21 \mathrm{~g} / 100$ $g$ depending on the botanical origin, the level of maturity reached in the hive, processing

The content of sugars in honey from bees of the genus Melipona

Table 2.

\begin{tabular}{|c|c|c|c|c|c|}
\hline Species & $\begin{array}{l}\text { Reducing sugars } \\
(\mathrm{g} / 100 \mathrm{~g})\end{array}$ & $\begin{array}{l}\text { Fructose } \\
(\mathrm{g} / 100 \mathrm{~g})\end{array}$ & $\begin{array}{l}\text { Clucose } \\
(\mathrm{g} / 100 \mathrm{~g})\end{array}$ & $\begin{array}{l}\text { Sucrose } \\
(\mathrm{g} / 100 \mathrm{~g})\end{array}$ & Source \\
\hline M. asilvai & $66.0-76.2$ & п.г. & п.г. & $1.1-8.3$ & Souza et al. (2004) \\
\hline M. mandacacia & $64.3-82.1$ & п.г. & п.г. & $0.6-6.2$ & Alves et al. (2005) \\
\hline M. beecheii & п.г. & 31.9 & 27.6 & 9.1 & Vit et al. (2006) \\
\hline M. favosa & п.г. & 32.2 & 28.6 & 4.6 & Vit et al. (2006) \\
\hline $\begin{array}{c}\text { M. compressipes } \\
\text { manaoense y M. seminigra } \\
\text { merribae }\end{array}$ & п.г. & $30.7-32.0$ & $28.6-29.8$ & $0.1-0.2$ & Almeida et al. (2007) \\
\hline M. scutellaris & $53.9-57.0$ & п.г. & п.г. & $1.1-3.2$ & Carvalho et al. (2009) \\
\hline M. quadrifasciata & $60.1-60.4$ & п.г. & п.г. & 1.3 & Carvalho et al. (2009) \\
\hline M. beecheii & 68.8 & п.г. & п.г. & 3.5 & Dardón \& Enríquez (2008) \\
\hline M. solani & 76.0 & п.г. & п.г. & 1.7 & Dardón \& Enríquez (2008) \\
\hline M. beecheii & п.г. & 31.8 & 37.3 & 3.2 & Gutiérrez et al. (2009) \\
\hline M.solani & п.г. & 30.2 & 31.9 & 6.8 & Gutiérrez et al. (2009) \\
\hline M. subnitida & п.г. & 29.2 & 21.8 & 4.9 & Almeida et al. (2013) \\
\hline M. beecheii & п.г. & 34.1 & 29.3 & 6.5 & Fonte et al. (2013) \\
\hline M. subnitida & $50.5-72.8$ & п.г. & п.г. & п.г. & Silva et al. (2013) \\
\hline M. beecheii & $57.1-74.2$ & п.г. & п.г. & п.г. & Moo et al. (2015) \\
\hline M. bicolour & $57.7-61.9$ & $31.5-34.7$ & $26.0-29.0$ & п.г. & Biluca et al. (2016) \\
\hline M. quadrasciata & $54.9-69.6$ & $30.4-39.4$ & $24.0-31.0$ & п.г. & Biluca et al. (2016) \\
\hline M. marginata & $60.5-70.5$ & $33.4-40.5$ & $26.0-29.0$ & п.г. & Biluca et al. (2016) \\
\hline M. mondury & $65.8-69.1$ & $36.4-38.9$ & $29.5-30.1$ & п.г. & Biluca et al. (2016) \\
\hline M. arufivestris mondory & 65.6 & 35.6 & 30.1 & п.г. & Biluca et al. (2016) \\
\hline M. scutellaris & 62.7 & 36.4 & 26.3 & п.г. & Biluca et al. (2016) \\
\hline M. subnida & $63.2-71.2$ & $50.0-59.2$ & $37.7-45.7$ & $0.7-3.9$ & Sousa et al. (2016) \\
\hline M. scutellaris & $62.7-71.2$ & $53.6-57.6$ & $38.1-43.3$ & $1.9-3.0$ & Sousa et al. (2016) \\
\hline $\begin{array}{l}\text { M. compressipes manoa- } \\
\text { sensis y M. seminigra }\end{array}$ & $52.9-81.6$ & ก.г. & п.г. & ก.г. & Gomes et al. (2017) \\
\hline M. asilvai & 63.4 & п.г. & п.г. & п.г. & Oliveira et al. (2017) \\
\hline M. q. anthidiodes & 65.6 & п.г. & п.г. & п.г. & Oliveira et al. (2017) \\
\hline M. q. quadrifasciata & 60.6 & п.г. & п.г. & п.г. & Oliveira et al. (2017) \\
\hline M. mandacacia & 34.8 & ก.г. & ก.г. & п.г. & Oliveira et al. (2017) \\
\hline M. scutellaris & 64.2 & ก.г. & п.г. & п.г. & Oliveira et al. (2017) \\
\hline M. compressipes & 78.9 & ก.г. & ก.г. & п.г. & Oliveira et al. (2017) \\
\hline M. subnitida & 64.2 & ก.г. & ก.г. & п.г. & Oliveira et al. (2017) \\
\hline M. mondury & 65.4 & п.г. & п.г. & 2.1 & Alves et al. (2018) \\
\hline M. scutellaris & 59.0 & п.г. & п.г. & п.г. & Duarte et al. (2018) \\
\hline M. q. anthidioides & 75.0 & п.г. & п.г. & п.г. & Duarte et al. (2018) \\
\hline M. subnitida & 75.0 & п.г. & п.г. & п.г. & Duarte et al. (2018) \\
\hline M. asilvai & 67.0 & п.г. & ก.г. & п.г. & Duarte et al. (2018) \\
\hline M. fasciculate & $50.1-52.6$ & п.г. & п.г. & п.г. & Fernandes et al. (2018) \\
\hline $\begin{array}{l}\text { M. scutellaris y Melipona sp } \\
\text { (Jandaíra) }\end{array}$ & $42.9-55.6$ & п.г. & п.г. & $1.4-6.1$ & Vale et al. (2018) \\
\hline
\end{tabular}

n.r. - not reported 
techniques and storage conditions (Yücel \& Sultanoglu, 2013). The moisture content is one of the most important characteristics influencing the physical properties of honey including viscosity, crystallization, color, taste, flavor, specific gravity, solubility and conservation (Escuredo et al., 2013).

The percentage of moisture in honey also varies in regions with high relative humidity, depending on the rainy season (Karabagias et al., 2014) and therefore on the vegetation. Moguel et al. (2005) reported that honey from trees and vines, mainly leguminous and convolvulaceous, registered during the period from November to December, after the rainy season in the Yucatan Peninsula, presented a higher average moisture $(19.2 \pm 0.7 \%)$ than the Tajonal honey $(18.0 \pm 0.8 \%)$, botanical resource used by bees in the dry season. Moguel et al. (2005) reported that honey from trees and vines, mainly leguminous and convolvulaceous, registered during the period from November to December, after the rainy season in the Yucatan Peninsula, presented a higher average humidity $(19.2 \pm 0.7 \%)$ than the Tajonal honey (18.0 $\pm 0.8 \%)$ botanical resource used by bees in the dry season.

The moisture percentages of the $M$. favosa and M. trinitatis honeys, $31.20 \%$ and $32.20 \%$ respectively, as determined by Bijlsma et al. (2006) were similar to those reported by Almeida et al. (2007) for M. compressipes manaoense and M. seminigra merribae with $30.13 \%$ and an Aw of 0.75 . However, M. subnitida honey was determined by Silva et al. (2013) to range from 22.3 to $23.0 \%$, very low values compared to what had been reported by Biluca et al. (2016) for M. quadrifasciata honey with a value of up to $43.5 \%$ moisture.

Regarding M. beecheii, Vit et al. (2006) described a value of $24.5 \%$ moisture in honeys from Venezuela, while Fonte et al. (2013) found a value of $24.0 \%$ for honey from the same species in Matanzas (Cuba). Similar information was reported by Grajales et al. (2018) for honey collected in 2000 in Chiapas, Mexico but not for honey collected in 2008, which shows an increase of more than one percentage unit, $25.3 \%$, while Moo et al. (2015) reported values between 21 and $25.3 \mathrm{~g} / 100 \mathrm{~g}$. The range of moisture content presented in Tab. 3 is between 17.32\% (Dardón \& Enríquez, 2008) and 45.8\% (Vale et al., 2018). The moisture values for $M$. quadriasciata is as high as $43.50 \%$ in Brazil (Biluca et al., 2016) which can be explained by the relationship of this type of honey to a climate with high relative humidity and the collection of nectar from low vegetation flowers and water-rich fruits (Tab. 3) (Ramón et al., 2015). Vit et al. (2004) stablished that a maximum of 30.0 is an adequate percentage of moisture in Melipona, Scaptotrigona and Trigona stingless bee honeys genera due to the environmental conditions in which these types of honeys are produced. However, studies have shown significant differences in honey moisture content among the different genera of stingless bee. Bijlsma et al. (2006) reported that the honey of such smaller species as Plebeia tobagoensis and Trigona nigra showed much higher average moisture values than those observed in the genus Melipona, which may be related to the nests of small species usually found at a low altitude from the ground and in rather humid conditions. Similarly, some stingless bee genera open or keep the honey pots open for use, rather than closing them and allowing the honey to mature (Torres et al., 2004). Therefore, in order to establish a more precise parameter of moisture content in this type of honey, research should include data on the environment and context of the colonies.

Moisture in honey can also increase during harvesting as well as in inadequate storage conditions since honey is hygroscopic and absorbs moisture from the atmosphere (Karabagias et al., 2014). In respect to the water activity (Aw), the honey presents a range between 0.49 to 0.65 (Mossel et al., 2003), which means that it is a product with a long shelf life even without refrigeration, does not require hydration to be consumed and can be considered as microbiologically safe. The Aw values of honey above 0.60 represent a critical threshold for microbial stability (Yücel \& Sultanoglu, 2013). Although there are no limits imposed by standards, the Aw value is known 
Table 3.

The moisture content of honey from bees of the genus Melipona

\begin{tabular}{|c|c|c|}
\hline Species & Moisture (\%) & Source \\
\hline M. asilvai & $26.8-32.0$ & Souza et al. (2004) \\
\hline M. mandacacia & $23.1-32.5$ & Alves et al. (2005) \\
\hline M. scutellaris & 25.3 & Evangelista et al. (2005) \\
\hline M. favosa & 31.2 & Bijlsma et al. (2006) \\
\hline M. trinitatis & 32.2 & Bijlsma et al. (2006) \\
\hline M. beecheii & 24.5 & Vit et al. (2006) \\
\hline M. favosa & 28.3 & Vit et al. (2006) \\
\hline $\begin{array}{c}\text { M. compressipes manaoense y M. seminigra } \\
\text { merribae }\end{array}$ & $24.8-30.6$ & Almeida et al. (2007) \\
\hline M. scutellaris & $26.0->30.0$ & Carvalho et al. (2009) \\
\hline M. quadrifasciata & $25.2->30.0$ & Carvalho et al. (2009) \\
\hline M. beecheii & 17.3 & Dardón et al. (2008) \\
\hline M. solani & 19.7 & Dardón et al. (2008) \\
\hline M. yucatanica & 20.4 & Dardón et al. (2008) \\
\hline M. beecheii & 27.2 & Gutiérrez et al. (2009) \\
\hline M. solani & 23.7 & Gutiérrez et al. (2009) \\
\hline M. capixaba & $22.8-36.0$ & Lage et al. (2012) \\
\hline M. subnitida & 24.8 & Almeida et al. (2013) \\
\hline M. beecheii & 24.0 & Fonte et al. (2013) \\
\hline M. subnitida & $20.2-24.4$ & Silva et al. (2013 ) \\
\hline M. beecheii & $21.0-25.3$ & Moo et al. (2015) \\
\hline M. bicolour & 28.8 - 39.1 & Biluca et al. (2016) \\
\hline M. quadrasciata & $25.9-43.5$ & Biluca et al. (2016) \\
\hline M. marginata & $28.3-38.2$ & Biluca et al. (2016) \\
\hline M. mondury & 29.6 - 29.9 & Biluca et al. (2016) \\
\hline M. arufivestris mondory & 27.7 & Biluca et al. (2016) \\
\hline M. scutellaris & 23.4 & Biluca et al. (2016) \\
\hline M. subnida & $23.9-28.9$ & Sousa et al. (2016) \\
\hline M. scutellaris & $24.3-26.5$ & Sousa et al. (2016) \\
\hline $\begin{array}{l}\text { M. compressipes manoasensis y } \\
\text { M. seminigra }\end{array}$ & $19.2-28.4$ & Gomes, et. al. (2017) \\
\hline M. beecheii & 28.6 & Alvarez et al. (2018) \\
\hline M. mondury & 29.2 & Alves et al. (2018) \\
\hline M. scutellaris & 30.0 & Duarte et al. (2018) \\
\hline M. q. anthidioides & 31.0 & Duarte et al. (2018) \\
\hline M. subnitida & 27.0 & Duarte et al. (2018) \\
\hline M. asilvai & 30.0 & Duarte et al. (2018) \\
\hline M. fasciculate & $23.7-27.2$ & Fernandes et al. (2018) \\
\hline M. beecheii & $25.3-27.0$ & Grajales et al. (2018) \\
\hline M. solani & $25.0-25.8$ & Grajales et al. (2018) \\
\hline M. scutellaris y Melipona sp (Jandaíra) & $27.7-45.8$ & Vale et al. (2018) \\
\hline
\end{tabular}

to be very important, because honey contains osmophilic yeasts that cause fermentation, forming ethyl alcohol and carbon dioxide, thus changing the quality of the honey (Tornuk et al., 2013; Yücel \& Sultanoglu, 2013).

\section{Free acidity and $\mathrm{pH}$}

Although the $\mathrm{pH}$ limit of honey has not yet been described by any regulatory committee, a natural $\mathrm{pH}$ set between 3.2 and 4.5 allows the inhibition of the growth of microorganisms, as the optimum for most microorgan- 
isms is between 7.2 and 7.4 (Karabagias et al., 2014). However, the Malaysian Standard (MS 2683:2017) has agreed to set a $\mathrm{pH}$ range of 2.5 to 3.8 for stingless bee honeys (Nordin et al., 2018).

The free acidity content is an indirect measure of freshness in honey and expresses the acidity independently of the acids present, which originate from secretions of bees' salivary glands that carry out the enzymatic and fermentation processes. Three types of acidity can be distinguished in honey: free, lactic and total. The relationship between lactonic acidity and free acidity shows whether honey is of floral or honeydew origin, while total acidity is a sum of the previous ones (Guadalix et al., 2002).

Although more than twenty organic acids have been found to be present in honey, gluconic acid is the most abundant and results mainly from glucose splitting due to the action of the glucose oxidase enzyme. Gluconolactone is produced as an intermediate product in this reaction, which also influences the concentration of acidity (Moguel et al., 2005). This transformation has been observed to be slow in dense honeys and rapid in fluid honeys, and the amount of acid depends on the quality and volume of nectar flow as well as on the time that elapses between its collection and storage (Zandamela, 2008). In the honey subjected to high temperatures, hydroxymethylfurfural (HMF) may be produced through the dehydration of hexose, mainly fructose, which in turn will form levulinic and formic acids when degraded, which will increase acidity levels (ICMSF, 2001).

Codex Alimentarius for honey allows a maximum free acidity value of $50.00 \mathrm{meq} / \mathrm{kg}$ (CXS 12, 1981). Higher values may be indicators of fermentation of sugars into organic acids. However, the presence of different organic acids, geographical origin and harvesting season can affect the acidity of the honeys (Tornuk et al., 2013). Souza et al. (2006) reported that the free acidity is lower in Melipona spp. honey (41.6 $\mathrm{meq} / \mathrm{kg}$ ) than in other genera of the Meliponini tribe (49.6 meq/kg).

In thirty-three samples analyzed by Biluca et al. (2016) the observed $\mathrm{pH}$ values ranged between
3.33, for $M$. quadrifasciata, and 6.56, for $M$. mondury. Souza et al. (2004) described a pH range of $3.14-3.40$ and an acidity of 21.50 $80.50 \mathrm{meq} / \mathrm{kg}$ for M. asilvai honey, while Silva et al. (2013) reported a wider $\mathrm{pH}$ range of 2.90 - 3.83 and a lower acidity range 24.66 - 59.66 $\mathrm{meq} / \mathrm{kg}$ for honey of M. subnitida. Contrarily, Duarte et al. (2018) mention similar mean $\mathrm{pH}$ values for honeys from M. scutellaris (4.2 \pm 0.9$)$ M. q. anthidiodes (4.2 \pm 0.7$),$ M. subnitida $(4.6 \pm 0.5)$ and M. asilvai $(4.3 \pm 0.5)$.

While Vit et al. (2006) described a pH from 3.67 to 4.07 and acidity from 18.90 to $11.83 \mathrm{meq} / \mathrm{kg}$, for M. favosa and M. beecheiirespectively, Fonte et al. (2013) found different values for the latter species, pH 3.6 and a free acidity of $35.0 \mathrm{meq} / \mathrm{kg}$. As observed in most studies, the free acidity was not related to the honey $\mathrm{pH}$, and the acidity of stingless bee honey was higher compared to that of $A$. mellifera (Tab. 4). Vit at al. (2004) suggested maximum acidity of 70 - $85 \mathrm{meq} / 100$ $\mathrm{g}$ to be the standard for non-fermented honey, and although fermented stingless bee honey is believed to be more effective for respiratory tract disorders, this should only be allowed as a result of a controlled process and a reproducible final product.

\section{Ash and electrical conductivity}

Ash content is a quality measure that evaluates the concentration of minerals present in honey. The mineral content indicates the geographical origin and environmental pollution, since it depends on the type of soil where the vegetation from which the nectar was collected is located (Karabagias et al., 2014). This can be seen in Tab. 5, where values of percentage of ash in honey are presented as low as $0.01 \%$ and up to $0.60 \%$ for the same species M. beecheii.

Although the Codex Alimentarius for honey does not provide a standard value for ash content, several studies have shown that the average in honey is $0.17 \%$, with a variation between $0.02 \%$ and $1.03 \%$ (Chakir et al., 2011), while the Mexican standard (NMX, 2006) set a maximum of $0.60 \%$. Because the electrical conductivity is directly related to the ash content, the Codex Alimentarius (CXS 12, 1981) recently 
Table 4.

The $\mathrm{pH}$ and free acidity of honey from bees of the genus Melipona

\begin{tabular}{|c|c|c|c|}
\hline Species & $\mathrm{pH}$ & Free acidity (meq/kg) & Source \\
\hline M. asilvai & $3.1-3.4$ & $21.5-80.5$ & Souza et al. (2004) \\
\hline M. mandacacia & $3.2-3.5$ & $18.5-62.5$ & Alves et al. (2005) \\
\hline M. scutellaris & 4.7 & 28.3 & Evangelista et al. (2005) \\
\hline M. beecheii & 4.1 & 11.8 & Vit et al. (2006) \\
\hline M. favosa & 3.7 & 18.9 & Vit et al. (2006) \\
\hline $\begin{array}{c}\text { M. compressipes manaoense y } \\
\text { M. seminigra merribae }\end{array}$ & $3.4-4.1$ & $20.6-27.8$ & Almeida et al. (2007) \\
\hline M. scutellaris & $3.5-3.6$ & $25.7-55.0$ & Carvalho et al. (2009) \\
\hline M. quadrifasciata & $3.7-6.6$ & $6.2-28.0$ & Carvalho et al. (2009) \\
\hline M. beecheii & 3.7 & 23.2 & Dardón et al. (2008) \\
\hline M. solani & 3.8 & 4.9 & Dardón et al. (2008) \\
\hline M. yucatanica & 3.8 & 10.6 & Dardón et al. (2008) \\
\hline M. beecheii & 5.1 & 29.7 & Gutiérrez et al. (2009) \\
\hline M. solani & 5.0 & 29.2 & Gutiérrez et al. (2009) \\
\hline M. capixaba & $3.3-3.8$ & $25.0-107.0$ & Lage et al. (2012) \\
\hline M. rufiventris & $4.0-4.5$ & $1.0-52.0$ & Lage et al. (2012) \\
\hline M. mondury & $3.2-5.7$ & $2.1-122.5$ & Lage et al. (2012) \\
\hline M. subnitida & ก.г. & 32.5 & Almeida et al. (2013) \\
\hline M. beecheii & 3.6 & 35.0 & Fonte et al. (2013) \\
\hline M. subnitida & $2.9-3.8$ & $24.7-59.7$ & Silva et al. (2013) \\
\hline M. beecheii & $2.6-3.3$ & $13.0-71.3$ & Moo et al. (2015) \\
\hline M. bicolour & 3.8 & $63.3-139.9$ & Biluca et al. (2016) \\
\hline M. quadrasciata & $3.3-4.3$ & $21.4-106.0$ & Biluca et al. (2016) \\
\hline M. marginata & $3.4-4.0$ & $42.4-120.0$ & Biluca et al. (2016) \\
\hline M. mondury & $3.8-6.6$ & $16.2-106.0$ & Biluca et al. (2016) \\
\hline M. arufivestris mondory & 4.2 & 38.2 & Biluca et al. (2016) \\
\hline M. scutellaris & 4.5 & 28.7 & Biluca et al. (2016) \\
\hline M. subnida & $3.1-5.3$ & п.г. & Sousa et al. (2016) \\
\hline M. scutellaris & $3.5-4.2$ & ก.г. & Sousa et al. (2016) \\
\hline $\begin{array}{l}\text { M. compressipes manoasensis y } \\
\text { M. seminigra }\end{array}$ & $2.8-3.6$ & п.г. & Gomes et al. (2017) \\
\hline M. beecheii & 3.2 & 41.5 & Alvarez et al. (2018) \\
\hline M. mondury & 4.1 & 34.3 & Alves et al. (2018) \\
\hline M. scutellaris & 4.2 & 37.0 & Duarte et al. (2018) \\
\hline M. q. anthidioides & 4.2 & 17.0 & Duarte et al. (2018) \\
\hline M. subnitida & 4.6 & 22.0 & Duarte et al. (2018) \\
\hline M. asilvai & 4.3 & 22.0 & Duarte et al. (2018) \\
\hline M. fasciculate & $3.8-4.9$ & $27.5-30.6$ & Fernandes et al. (2018) \\
\hline M. beecheii & $3.6-4.2$ & $5.9-40.3$ & Grajales et al. (2018) \\
\hline M. solani & $3.6-4.0$ & $55.8-85.0$ & Grajales et al. (2018) \\
\hline M. scutellaris y Melipona sp (Jandaíra) & $3.0-4.4$ & $23.8-61.5$ & Vale et al. (2018) \\
\hline
\end{tabular}

ก.r. - not reported

included it and recommended a maximum value of $0.80 \mathrm{mS} / \mathrm{cm}$ equivalent to $800.00 \mu \mathrm{S} / \mathrm{cm}$. For M. mandacaia honey, Alves et al. (2005) reported an average conductivity of $350.0 \mu \mathrm{S} /$ $\mathrm{cm}$, a value similar to the one reported by Souza et al. (2004) for M. asilvai honey and Sousa et al. (2016) for M. subnida honey.

Gutiérrez et al. (2009) reported an electrical conductivity of $150.0 \mu \mathrm{S} / \mathrm{cm}$ for $M$. beecheii honey, a value very much below the range 
presented by Grajales et al. (2018) and Alvarez et al. (2018) with an electrical conductivity of $500-660$ and $580 \mu \mathrm{S} / \mathrm{cm}$ respectively. The electrical conductivity of the honey, besides being related to the content of ashes (minerals), is related to color and taste. The color is darker and the taste more acidic when the mineral content is higher (Karabagias et al., 2014). This acidity demonstrates the presence of ions, acids and organic proteins (Yücel \& Sultanoglu, 2013),

The electrical conductivity and ash content of honey from bees of the genus Melipona

Table 5.

\begin{tabular}{|c|c|c|c|}
\hline Species & $\begin{array}{c}\text { Electrical conductivity } \\
(\mu \mathrm{S} / \mathrm{cm})\end{array}$ & $\begin{array}{l}\text { Ash } \\
(\%)\end{array}$ & Source \\
\hline M. asilvai & $287.5-525.0$ & n.r. & Souza et al. (2004) \\
\hline M. mandacacia & $267.5-462.0$ & n.r. & Alves et al. (2005) \\
\hline M. scutellaris & n.r. & 0.17 & Evangelista et al. (2005) \\
\hline M. beecheii & n.r. & 0.02 & Vit et al. (2006) \\
\hline M. favosa & n.r. & 0.13 & Vit et al. (2006) \\
\hline M. scutellaris & $264.2-272.1$ & 0.18 & Carvalho et al. (2009) \\
\hline M. quadrifasciata & $226.0-445.9$ & $0.15-0.40$ & Carvalho et al. (2009) \\
\hline M. beecheii & n.r. & 0.07 & Dardón et al. (2008) \\
\hline M. solani & n.r. & 0.06 & Dardón et al. (2008) \\
\hline M. yucatanica & n.r. & 0.06 & Dardón et al. (2008) \\
\hline M. beecheii & 150.0 & n.r. & Gutiérrez et al. (2009) \\
\hline M. solani & 140.0 & n.r. & Gutiérrez et al. (2009) \\
\hline M. subnitida & 102.8 & 0.02 & Almeida et al. (2013) \\
\hline M. subnitida & n.r. & $0.03-0.20$ & Silva et al. (2013) \\
\hline M. beecheii & n.r. & $0.01-0.60$ & Moo et al. (2015) \\
\hline M. bicolour & $360.0-700.0$ & n.r. & Biluca et al. (2016) \\
\hline M. quadrasciata & $160.0-830.0$ & n.r. & Biluca et al. (2016) \\
\hline M. marginata & $270.0-700.0$ & n.r. & Biluca et al. (2016) \\
\hline M. mondury & $540.0-840.0$ & n.r. & Biluca et al. (2016) \\
\hline M. arufivestris mondory & 250.0 & n.r. & Biluca et al. (2016) \\
\hline M. scutellaris & 150.0 & n.r. & Biluca et al. (2016) \\
\hline M. subnida & $300.0-636.0$ & $0.04-0.52$ & Sousa et al. (2016) \\
\hline M. scutellaris & $340.0-670.0$ & $0.03-0.41$ & Sousa et al. (2016) \\
\hline $\begin{array}{c}\text { M. compressipes manoasensis } \\
\text { y M. seminigra }\end{array}$ & n.r. & $0.02-0.33$ & Gomes et al. (2017) \\
\hline M. beecheii & 580.0 & 0.46 & Alvarez et al. (2018) \\
\hline M. mondury & 391.5 & 0.18 & Alves et al. (2018) \\
\hline M. scutellaris & 700.0 & n.r. & Duarte et al. (2018) \\
\hline M. q. anthidioides & 500.0 & n.r. & Duarte et al. (2018) \\
\hline M. subnitida & 600.0 & n.r. & Duarte et al. (2018) \\
\hline M. asilvai & 300.0 & n.r. & Duarte et al. (2018) \\
\hline M. beecheii & $500.0-660.0$ & n.r. & Grajales et al. (2018) \\
\hline M. solani & $450.0-620.0$ & n.r. & Grajales et al. (2018) \\
\hline $\begin{array}{l}\text { M. scutellaris y Melipona sp } \\
\text { (Jandaíra) }\end{array}$ & $277.7-513.0$ & $0.24-0.49$ & Vale et al. (2018) \\
\hline
\end{tabular}

п.г. - not reported 


\section{_BAMÍREZ-MIRANDH Et Hl___Honey Standards of genus Melipona}

which means that a higher content results in greater conductivity.

Almeida et al. (2013) suggests that the maximum permitted value for the electrical conductivity of stingless bee honeys should be $500 \mu \mathrm{S} / \mathrm{cm}$, which is lower than for $A$. mellifera. However, Biluca et al. (2016) found values of up to 830 $\mu \mathrm{S} / \mathrm{cm}$ in M. quadrifasciata and $840 \mu \mathrm{S} / \mathrm{cm}$ for M. mondury honeys, so the parameter proposed by the former should be reconsidered.

\section{Color}

Honey color is an important parameter in quality, acceptance and consumer preference (Da Silva et al., 2016), because it is the result of the different degrees of absorption by honey constituents of the light wavelengths (Fattori, 2004). Color is one of the most variable parameters and depends on the content of minerals, pollen and phenolic compounds (Solayman et al., 2016). The color of honey is related to the formation of a series of brown compounds that originate when the organic matter of honey reacts with mineral salts (Gómez, 2004). Dark honeys contain higher levels of microelements than light honeys (Alqarni et al., 2014), and although the color range of honey in most cases may be from light yellow to amber, dark amber or even black, in some honeys green or red hues may be observed (Abu et al., 2017). Likewise, all honeys gradually acquire a darker coloration due to a set of non-enzymatic browning reactions known as Maillard's reactions (Can et al., 2015), which are favored by exposure to light, heat and storage time (Sousa et al., 2016).

Nordin et al. (2018) reported that honey with a higher color intensity has been detected in Tetragonisca angustula from Brazil and the lowest in Melipona ilota from Peru. Since no specification is mentioned in the legislation, the need for further research studies is justified (Silva et al., 2013). Almeida et al. (2013) reported that $79.17 \%$ of $A$. mellifera honey samples had a white coloration (16.5-34.0 mm Pfund) and $20.83 \%$ an extra light amber color (34.0-50.0 mm Pfund). Honey from M. subnitida $66.67 \%$ was extra white (8.0-16.5 mm Pfund) and $33.33 \%$ white (16.5-34.0 mm Pfund), so it could be concluded that there was a significant difference between the two types of honey, as $M$. subnitida honey was lighter than the A. mellifera.

Fonte et al. (2013) detected an extra light amber color (34.0-50.0 mm Pfund) for M. beecheii honey, which differs from Gutiérrez et al. (2009) who described a white (25.50 mm Pfund) color for the same species and extra white $(11.00 \mathrm{~mm}$ Pfund) for M. solani honey. Grajales et al. (2018) reported a dark amber (136.0 mm Pfund) and white (29.0 mm Pfund) for the same species, which could depend on their botanical origin, their composition, temperature and storage time (Terrab et al., 2002; Bogdanov et al., 2004). However, a large number of samples with these characteristics must be compared in order to be able to associate their organoleptic attributes, including color, with their entomological, botanical origin and composition (Vit et al., 2006).

\section{Hydroxymethylfurfural (HMF)}

HMF is an indicator of freshness, as it is generally absent in freshly harvested honey and tends to increase over time. HMF is a breakdown product of simple sugars, especially fructose. Several factors affect HMF content, including heating and storage conditions, as well as a honey's $\mathrm{pH}$ and adulteration with simple sugars from an external source (Pasias et al., 2017).

The range of HMF detected values in samples of $M$. asilvai honeys was $0.52-7.93 \mathrm{mg} / \mathrm{kg}$ (Souza et al., 2004), and the average value for M. mandacaia honey was $5.79 \mathrm{mg} / \mathrm{kg}$ (Alves et al., 2005). Gutiérrez et al. (2009) detected values of 0.12 and $0.20 \mathrm{mg} / \mathrm{kg}$ for $M$. beecheii and $M$. solani honeys respectively, although Dardón \& Enríquez (2008) reported even lower values for the same species, 0.10 and $0.00 \mathrm{mg} /$ $\mathrm{kg}$. Different results were published by Grajales et al. (2018) for M. beecheii (2.1 mg/kg) and for M. solani $(0.6 \mathrm{mg} / \mathrm{kg})$ in samples collected in 2008, while in 2000 the values increased to $64.8 \mathrm{mg} / \mathrm{kg}$ and $78.5 \mathrm{mg} / \mathrm{kg}$. With regard to the honeys of other analyzed meliponids, Grajales et al. (2018) mentioned that the highest value was for $M$. beecheii, which confirmed what Souza 
et al. (2006) when reported that HMF concentrations were higher in Melipona honey than in other meliponid genera.

Almeida et al. (2013) described that the HMF content in $A$. mellifera honey (10.32-12.27 $\mathrm{mg} / \mathrm{kg}$ ) was higher than that of $M$. subnitida (7.18-8.22 mg/kg). Contrarily, Biluca et al. (2016) did not detect quantifiable HMF concentrations in honeys of different genera including Melipona. Similar results reported by Sousa et al. (2016) for M. subnida and M. scutellaris honeys indicated that the samples were collected and stored under adequate conditions, and that stingless bee honey was more resistant to HMF formation than $A$. mellifera honey when it was heated (Biluca et al., 2016). Therefore, the Malaysian Department of Standardization has established that the maximum content of HMF for stingless bee honeys should be $30 \mathrm{mg} / \mathrm{kg}$ (Abu et al., 2017), while Vit et al. (2004) indicated that it should be kept at $<40 \mathrm{mg} / \mathrm{kg}$ as it has been established for honey from A.mellifera with less than six months of storage.

In some cases, stingless bee honeys are often considered adulterated because of their high HMF content associated with improper handling techniques or adverse weather conditions (Alves et al., 2005). Nevertheless, their HMF content is directly related to their higher natural moisture content. Therefore, a revision of the HMF standard for stingless bee honeys is of utmost importance (Nordin et al., 2018).

\section{Amino acids and proteins}

The concentration of amino acids and proteins in honey is relatively low, approximately $0.7 \%$ (Bogdanov, 2010), and depends on both its botanical and geographical origin as well as its storage time (Abu et al., 2017). Honey contains almost all physiologically important amino acids (Bogdanov, 2010), proline being the most abundant, followed by lysine, glutamic acid and aspartic acid (Cauich et al., 2015).

Almeida et al. (2013) found a significant difference in the protein content of honey produced by $A$. mellifera and $M$. subnitida, being $0.49 \%$ and $0.28 \%$ respectively. This value is similar to that reported by Silva et al. (2013) with a maximum value of $0.26 \%$ for the same Melipona species. Sousa et al. (2016) described that the average value of protein in $M$. subnida and $M$. scutellaris honeys was in the range of $0.2-0.5 \%$, even though there were significant difference between honeys made from the same floral source although produced by different species. While Oliveira et al. (2017) reported that among the honey from seven different Melipona species, the lowest value was for M.q. antihidiodes with $0.12 \%$ and the highest for M. asilvai with $0.39 \%$. The proline content of honey is a criterion criterion for its maturation and in some cases for adulteration. The normal value should be higher than $200 \mathrm{mg} / \mathrm{kg}$, because below 180 $\mathrm{mg} / \mathrm{kg}$, means that the honey is probably adulterated with added sugars (Bogdanov, 2010). In a review of scientific articles published between 1997 and 2014 by Solayman et al. (2016) a range of $114.35-2131 \mathrm{mg} / \mathrm{g}$ of proline content was detected in A.mellifera honeys from different regions, with a mean of $873.28 \mathrm{mg} / \mathrm{kg}$. With regard to the meliponidae honey, there are few investigations that determine its content. Sousa et al. (2016) reported a range between 4.6 and $20.5 \mathrm{mg} / \mathrm{kg}$ for M. subnida and M. scutellaris honeys, which is as a much lower range compared to what was described by Moo et al. (2015) with values from 264.50 to 1193.70 for $M$. beecheii honeys as well as with the standard for $A$. mellifera honey.

Enzymes are the main protein component in honey added by bees during the honey ripening process (Abu et al., 2017). Diastase (amylase), a relatively heat and storage stable enzyme, splits starch into maltose. Invertase (saccharase or $\alpha$-glucosidase), primarily catalyzes the conversion of sucrose to glucose and fructose. Other enzymes such as glucose oxidase and catalase regulate the production of hydrogen peroxide, one of the antibacterial factors in honey (Bogdanov, 2010).

Although the diastase and invertase activity present a wide variability they are used as indicators to evaluate the quality of the honey. The diastase activity is expressed as the diastase number (DN) in Schade units or Göthe units and both the Codex Alimentarius 


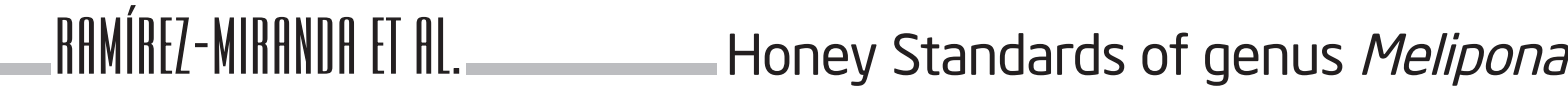

(CSX 12, 1981) and the European Directive (EU, 2002) establishes a minimum value of 8.0 Schade units. Huidobro \& Simal (1984) reported that this activity declines during the storage and heating of honey, reaching up to $50 \%$ in seventeen months at room temperature. Because invertase is more susceptible to decay unlike diastase, it is not often included in quality standards, but in some countries it is used as an indicator to determine whether a honey is virgin (not heated) and freshly harvested. Such honeys should contain at least ten Hadron invertase units (IU) or sixty-four international units, while honeys with low enzyme activity should have a minimum value of four units (Bogdanov, 2010). Souza et al. (2006) in a review of scientific articles published between 1964 and 2005 found ranges of 0.9-23.0 for diastase and 19.8-90.1 for invertase in Melipona, Scaptotrigona and Tetragonisca species. Although values as high as 21.29, 8.31 and 10.04 units are referred by Dardón \& Enríquez (2008) for honeys of M. beecheii, M. solani and M. yucatanica, most researchers report $<3.00$ units, reducing the diastase standard to this value is proposed by Vit et al. (2004), based on previous studies that show that honey of the genus Melipona presents low values without necessarily meaning a lack of quality. In fact, Alves et al. (2018) mentioned that high diastase values are probably related to accidental feeding with the honey of $A$. mellifera within some colonies of Melipona.

\section{Insoluble solids}

Honey-insoluble matter includes bee pollen, honeycomb debris, bee and dirt particles, and as such, this parameter is a criterion for cleanliness since it allows the detection of impurities in honeys (Almeida et al., 2013). During the extraction process, the honey may become contaminated with insoluble solids, so it must be filtered so that insect remains, grains of sand, pieces of honeycomb and wax are eliminated. According to the Codex Alimentarius (CSX 12, 1981), the maximum allowed value of insoluble solids present in honey in general is $0.1 \%$ and for pressed honey $0.5 \%$.

Few studies have analyzed the content of insoluble solids in stingless honey, which makes comparisons difficult. However, Vit et al. (2016) mentions that for Tetragonisca the content of insoluble solids was $0.06 \pm 0.02 \%$ which coincides with that published for honeys from Brazil, which is associated with the implementation of good practices during honey management, while Fernandes et al. (2018) reported 0.09-0.11\% for M. facsiculata. It would be important that the articles published refer to the technique of extraction during the harvest and handling of honey in order to establish a relationship with the percentage of insoluble solids detected.

\section{Microbiological characterization of honey}

In honey, the growth of many microorganisms is limited due to their intrinsic properties such as: high osmotic pressure due to low water activity (0.5-0.65) (Chen, 2019); low pH (average 3.9)due to the presence of organic acids, mainly gluconic acid; the presence of hydrogen peroxide generated by the action of the enzyme glucose oxidase; low protein content; low redox potential due to the presence of reducing sugars; and chemical agents present such as lysozyme, phenolic acids, pinocembrine, terpenes, benzyl alcohol and volatile substances (Rao et al., 2016). The few microorganisms that can develop or remain dormant in honey are derived from primary or secondary sources of contamination. Sources of primary contamination, which are virtually impossible to avoid because they occur naturally, include pollen, honeybee digestive extracts, dust, air, soil, and nectar (Różańska \& Osek, 2016). Secondary sources are due to honey handlers and processors, facilities, equipment, and utensils, and are easily controlled through the implementation of good manufacturing practices (GMP) (Kačániová et al., 2009; Grabowski \& Klein, 2015; Olaitan et al., 2017).

In Mexico, the current NOM-004-SAG/GAN-2018 (NOM, 2018) does not mention the sanitary quality of honey, but NMX-036-NORMEX-2006 (NMX, 2006) establishes that the presence of a maximum value of 1000 CFU/g of non-pathogenic bacteria and up to 100 CFU/g of yeasts and molds are accepted. The Ministry of Health 
in Peru established a maximum of $10^{4} / \mathrm{g}$ for mesophilic aerobes and $10^{2} / g$ for both moulds and sulphite-reducing aerobes as well as presented a three-class sampling plan for these indicators. The European Microbiological Standard for honey destined for the Spanish market and the European Union established the following: mesophilic aerobes - $10^{4} / \mathrm{g}$, enterobacteria - absence in $1 \mathrm{~g}, E$. coli - absence in $1 \mathrm{~g}$, Salmonella or Shigella - absence in $25 \mathrm{~g}$; moulds 102/g (Moragas et al., 2019).

Among the sporulating bacteria, spores of Clostridium botulinum and, to a lesser extent, of Clostridium perfringens have been detected (Grenda et al., 2018 a,b). C. botulinum has been linked to infant botulism in children less than one year of age (Aureli et al., 2002), while C. perfringens may cause gastrointestinal disturbances or gangrene in deep wounds, due to the current use of honey as a therapeutic agent in wounds (Olaitan et al., 2007).

Although honey is a microbiologically safe food, some studies have shown that it contains the presence not only of aerobic mesophilic bacteria, moulds and yeasts, but also of such lactic acid bacteria (LAL) as Lactobacillus spp. and Enterococcus spp., fructophilic acid bacteria (FLAB) predominantly L. kuneii, of recent interest as a probiotic. It can also present coliforms and pathogens such as Staphylococcus aureus, Salmonella spp. and spores of Bacillus cereus, $C$. perfringens and $C$. botulinum (Coll et al., 2008; Pajor etal., 2018; Vázquez etal., 2018). Salamanca et al. (2000) demonstrated that certain species of Salmonella are capable of resisting for thirtyfour days in honey maintained at $10^{\circ} \mathrm{C}$.

There have been few studies on the microbiological characterization of honey from stingless bee and the genus Melipona. Since this honey has been used in traditional medicine for years, it is sufficient to state that it is free from any microbiological hazard. However, Mendes da Escóssia et al. (2018) reported that of thirtyfive samples from M. subnitida in Brazil, all were positive for aerobic mesophiles, coliforms, moulds and yeasts, while in $85.7 \%$ for $S$. aureus and in $34.3 \%$ for Bacillus spp., Clostridium perfringens and C. botulinum were detected through molecular tests in $40 \%$ and $2.8 \%$ of the samples, respectively. Contrary to what was reported by Zamora \& Arias (2011) with respect to the absence of $C$. botulinum in the evaluation of the 30 samples tested on Costa Rica stingless bee honeys.

Similarly, Fernández et al. (2018) reported that all samples of melipona honey obtained from four ecosystems in the municipality of Abreus, province of Cienfuegos (Cuba), complied with the international requirements. All samples presented microbiological characteristics suitable for consumption and marketing, despite the fact that in all ecosystems there was an integration of agriculture-livestock or backyard farming, and in some cases wastewater within the flight range of the bees. The Meliponini tribe interact mutually with microorganisms including acid-lactic bacteria in Australian species such as Tetragonula carbonaria, T. hockingsi and Austroplebeia (Leonhardt \& Kaltenpoth, 2014); yeasts in Starmerella meliponinorum, Starmerella neotropicalis, Candida apicola and Zygosaccharomyces spp., and in neotropical species such as Tetragonisca angustula, Frieseomelitta varia, Melipona quinquefasciata and Melipona quadrifasciata (Rosa et al., 2003; Teixeira et al., 2003) and provide sensory and conservation characteristics to honey (Salgado et al., 2017). With regard to moulds, bees grow them as food (Oldroyd \& Aanen, 2015) and protection against other pathogenic microorganisms (Menezes et al., 2013).

Although stingless bee microorganisms are useful to honey beekeepers because they make such products as mead, honey and pollen jelly or a creamy pollen shake (Menezes et al., 2013), little is known about the pathogens in this type of bee (Nunes et al., 2016). However, because honey from these bees is currently used in folk medicine (Vit et al., 2004; Vit et al., 2015) specific parameters must be met to ensure that this product does not endanger the health of those who use it. For example, the Official Gazette of the Republic of Argentina established to Tetragonisca fiebrigi honey, maximum limits for $E$. coli (absence in $1 \mathrm{~g})$, Salmonella spp. (absence in $25 \mathrm{~g}$ ) and fungi and yeasts $\left(10^{3}-10^{4}\right.$ 
CFU/g). As observed in this case, the limits for moulds and yeasts exceed those established for $A$. mellifera honey in the Mexican standard (NMX, 2006) because stingless bee honeys have a higher Aw whose proliferation is favored. The presence of mold spores may not be considered a direct problem in honey because the low $\mathrm{pH}$ and the low availability of nutrients, inhibit their germination and therefore the mycelial growth. However, the osmophilic and osmotolerant yeast type are able to survive and proliferate in this matrix and produce some of the sensory characteristics in this type of honey through their metabolism on sugars can cause undesirable changes if a limit is not established.

\section{Conclusions}

According to the consulted investigations, the honey of the Melipona bees stands out for its higher water content and acidity in accordance with the Codex Alimentarius. The sensory characteristics of Melipona honey related to a possible fermentation of sugars and the way of storing the honey inside its nests in cerumen pots (mixture of wax and vegetable resin) are sufficient reasons to consider this honey as a different product that needs to be characterized and standardized in Mexico and international level for its commercialization.

Studies are limited with respect to the microbiology of the honey of the genus Melipona. However, the main microorganisms living in stingless bee colonies are yeasts, molds and bacteria which are not pathogenic to humans, of which in most cases their possible relationship with the hive or their function during the honey maturation process is unknown.

The sanitary quality of Melipona honey should be of greater interest for the entities interested in its use and commercialization because it has a high percentage of water and facilitates the presence and proliferation of microorganisms. Thus, research, educational and extension entities must promote among stingless beekeepers new technologies that contribute to practices prevent honey from being risk due to secondary contamination, especially since it is more used for therapy than as a food.

\section{ACKNOWLEDGMENTS}

The authors acknowledge doctoral fellowship support from Consejo Nacional de Ciencia y Tecnología, CONACyT

\section{Conflicts of interest}

The authors declare that there is no conflict of interest regarding the publication of this article.

\section{REFERENCES}

Abd, J.M.A., Kasmuri, A.R., Hadi, H. (2017). Stingless bee honey, the natural wound healer: A review. Skin Pharmacology and Physiology, 30(2), 66-75. DOl: 10.1159/000458416

Abu, B.M.F., Sanusi, S.B., Abu, B.F.l., Cong, O.I., Mian, Z. (2017). Physicochemical and antioxidant potential of raw unprocessed honey from Malaysian stingless bee. Pakistan Journal of Nutrition, 16(11), 888-894. DOl: 10.3923/pjn.2017.888.894

Almeida, M.L.B de., Stramm, K.M., Horita, A., Barth, O.M., Da Silva de Freitas, A., Estevinho, L.M. (2013). Comparative study of the physicochemical and palynological characteristics of honey from Melipona subnitida and Apis mellifera. International Journal of Food Science \& Technology, 48(8), 1698-1706. DOl: 10.1111/ijfs.12140

Almeida, M.L.B. de, Matsuda, A.H., Bastos, D.H. (2007). Physicochemical parameters of Amazon Melipona honey. Química Nova, 3033), 707-708. D01: 10.1590/ s0100-40422007000300033

Alqarni, A.S., Owayss, A.A., Mahmoud, A.A., Hannan, M.A. (2014). Mineral content and physical properties of local and imported honeys in Saudi Arabia. Journal of Saudi Chemical Society, 18(5), 618-625. DOl: 10.1016/j.jscs.2012.11.009

Alvarez, S.M., Giampieri, F., Brenciani, A., Mazzoni, L., Gasparrini, M., Gonz, A. M., Battino, M. (2018). Apis mellifera vs Melipona beecheil Cuban polifloral honeys: A comparison based on their physicochemical parameters, chemical composition and biological properties. LWT - Food Science and Technology, 87, 


\section{2-279. DOl: 10.1016/j.lwt.2017.08.079}

Alves, O.R.M., De Carvalho, L.C.A., Souza, De A.B., Sodré, Da S.C., Marchini, L.C. (2005). Características físico-químicas de amostras de mel de Melipona mandacaia Smith (Hymenoptera: Apidae). Ciência e Tecnologia de Alimentos, 25(4), 644-650.

Arnold, N., Zepeda, R., Vásquez D.M.A., Aldasoro, M.M. (2018a). Las abejas sin aguijón y su cultivo en Oaxaca, México con catálogo de especies. ECOSURCONABIO: Chis, Méx.

Arnold, N., Ayala, R., Mérida, J., Sagot, P., Aldasoro, M., Vandame, R. (2018b). Registros nuevos de abejas sin aguijón (Apidae: Meliponini) para los estados de Chiapas y Oaxaca, México. Revista Mexicana de Biodiversidad, 89, 651-665. D0l: 10.22201/ ib.20078706e.2018.3.2429

Aureli, P., Franciosa, G., Fenicia, L. (2002). Infant botulism and honey in Europe: a commentary. Pediatric Infectious Disease Journal, 27(9), 866-868. DOl: 10.1097/00006454-200209000-00016

Ayala, R., Gonzalez, V.H., Engel, M.S. (2013). Mexican stingless bees (Hymenoptera: Apidae): Diversity, distribution, and indigenous knowledge. In PotHoney: A legacy of stingless bees, (pp. 135-152). Springer Science+Business Media, New York.

Bijlsma, L., Brujijn, L.L.M., Martens, E.P., Sommeijer, M.J. (2006). Water content of stingless bee honeys (Apidae, Meliponini): interspecific variation and comparison with honey of Apis mellifera. Apidologie, 374), 480-486. DOl: 10.1051/apido:2006034

Biluca, F.C., Braghini, F., Gonzaga, L.V., Costa, A.C.O., Fett, R. (2016). Physicochemical profiles, minerals and bioactive compounds of stingless bee honey (Meliponinae). Journal of Food Composition and Analysis, 50, 61-69. D0l: 10.1016/j.jfca.2016.05.007

Bogdanov, S. (2010). Honey in medicine, In Book of honey. Retrieved September 13, 2019, from https:// www.researchgate.net/publication/304011973_ Honey_in_Medicine
Bogdanov,S., Lüllmann,C,.,Martin,P.,Ohe,W., Russmann, H., Vorwohl, G., ... Vit, P. (2015). Honey quality and international regulatory standards: review by the International Honey Commission. Bee World, 80, 6169. DOl: 10.1080/0005772X.1999.11099428

Bogdanov, S., Ruoff, K., Persano O.S. (2004). Physicochemical methods for the characterization of unifloral honeys: a review. Apidologie, 35(1), S4-S17. DOl: 10.1051/apido:2004047

Can, Z., Yildiz, O., Sahin, H., Akyuz, E., Silici, S., Kolayli, S. (2015). An investigation of Turkish honeys: their physico-chemical properties, antioxidant capacities and phenolic profiles. Food Chemistry, 180, 133-141. DOl: 10.1016/j.foodchem.2015.02.024

Carvalho, C.A.L., Sodré, G.S., Fonseca, A.A.O., Alves, R.M.O., Souza, B.A., Clarton, L. (2009). Physicochemical characteristics and sensory profile of honey samples from stingless bee (Apidae: Meliponinae) submitted to a dehumidification process. Anais da Academia Brasileira de Ciências, 87(1), 143-149. DOI: 10.1590/ S0001-37652009000100015

Cauich, K.R., Ruiz, R.J.C., Ortiz, V.E., Segura, C.M.R. (2015). Potencial antioxidante de la miel de Melipona beecheii y su relación con la salud: Una revisión. Nutrición Hospitalaria, 32(4), 1432-1442. DOl: 10.3305/nh.2015.32.4.9312

Chakir, A., Romane, A., Barbagianni, N., Bartoli, D. (2011). Major and trace elements in different types of Moroccan honeys. Australian Journal of Basic and Applied Sciences, 5(4), 223-231.

Chen, C. (2019). Relationship between water activity and moisture content in floral honey. Foods, 8(30), 30. DOl: 10.3390/foods8010030

Coll, C.F., Villat, C., Laporte. G., Noia, M., Mestorino, N. (2008). Características microbiológicas de la miel. Revisión bibliográfica. Veterinaria Cuyana, 3(1-2), 29-34.

Cortopassi, L.M., Imperatriz, F.V.L., Roubik, D.W., Dollin, A., Heard, T., Aguilar, I., Noguera-Neto, P. (2006). Global meliponiculture: Challenges and 
opportunities. Apidologie, 372), 275-292. DOl: 10.1051/apido:2006027

CXS 12 (1981). Adopted in 1981. Revised in 1987, 2001. Amended in 2019. Standard for Honey. Codex Alimentarius International Food Standards.

Da Silva, P.M., Gauche, C., Gonzaga, L.V., Costa, A.C.O., Fett, R. (2016). Honey: Chemical composition, stability and authenticity. Food Chemistry, 196, 309-323. DOl: 10.1016/j.foodchem.2015.09.051

Dardón, J.M. \& Enríquez, E. (2008). Caracterización fisicoquímica y antimicrobiana de la miel de nueve especies de abejas sin aguijón (Meliponini) de Guatemala. Interciencia, 33(12), 916-922.

Duarte, A.W.F, Vasconcelos, M.R.S., Oda-Souza, M., Oliveira, F.F., López, A,M,Q. (2018). Honey and bee pollen produced by Meliponini (Apidae) in Alagoas, Brazil: multivariate analysis of physicochemical and antioxidant profiles. Food science and Technology, 38(3), 493-503. DOl: 10.1590/ fst.09317

Escuredo, O., Míguez, M., Fernández, G.M., Carmen, S.M. (2013). Nutritional value and antioxidant activity of honeys produced in a European Atlantic area. Food Chemistry, 138(2-3), 851-856. D0l: 10.1016/j. foodchem.2012.11.015

EU (2002). Council Directive 2001/110/EC of 20 December 2001 relating to honey. Official Journal, L $10,47-52$

Evangelista, R.A., Silva, E.M.S da., Beserra, E.M.F." Rodrigues, M.L. (2005). Análise físico-química dos méis das abelhas Apis melliferae Melipona scutellaris produzidos em regiões distintas no Estado da Paraíba. Ciência Rural, 35(5), 1166-1171. DOl: 10.1590/S0103-84782005000500028

Fattori, S.B. (2004). La miel: propiedades, composición y análisis físico-químico. Beekeeping Technology and Bee Products Commission. Apimondia. Retrieved September 26, 2019, https: //www.apiservices. biz/documents/artículoses/la_miel_propiedades_ composicion_y_analisis_fisico-quimico.pdf
Fernandes, R.T., Rosa, I.G., Conti, S.A.C. (2018). Microbiological and physical-chemical characteristics of honeys from the bee Melipona fasciculata produced in two regions of Brazil. Ciência Rural, 48(5), 1-8. DOl: 10.1590/0103-8478сr20180025

Fernández, G.N., Navarro, V.J.M., Martínez, M.J.A. (2018). Caracterización de la miel de Meliponas en ecosistemas periurbanos y agrícolas del Consejo Popular Horquita. Revista Científica Agroecosistemas, 6(1), 28-33.

Fonte, L., Díaz, M., Machado, R., Demedio, J., García, A., Blanco, D. (2013). Caracterización físico-química y organoléptica de miel de Melipona beecheii obtenida en sistemas agroforestales. Pastos y Forrajes, 36(3), 345-349.

Gomes, V.V., Dourado, G.S., Costa, S.C., Lima, A.K.O., Silva, D.S., Bandeira, A.M.P., Taube, P.S. (2017). Artigo Avaliação da Qualidade do Mel Comercializado no Oeste do Avaliação da Qualidade do Mel Comercializado no Oeste do Pará, Brasil. Revista Virtual de Química, 9(2), 815-826. D0l: 10.21577/1984-6835.20170050

Gómez, P.A. (2004). Mieles de España y Portugal: conocimiento y cata. Montagud: Barcelona, España.

González, A.J. (2012). La importancia de la meliponicultura en México, con énfasis en la Península de Yucatán. Bioagrociencias, 5(1), 34-42.

González, A.J., \& Quezada, J. (2010). Producción tradicional de miel: abejas nativas sin aguijón (trigonas y meliponas). In Biodiversidad y Desarrollo Humano en Yucatán. (pp. 382-384). CICY, PPDFMAM, CONABIO, SEDUMA, Mérida, Yucatán,

Grabowski, N.T., \& Klein, G. (2015). Microbiology and foodborne pathogens in honey. Critical Reviews in Food Science and Nutrition, 579), 1852-1862. DOl: 10.1080/10408398.2015.1029041

Grajales, C..., Vandame, R., Santiesteban, A., López, A., Guzmán, D.M. (2018). Propiedades fisicoquímicas y antibacterianas de mieles de abejas sin aguijón del 
Sur de Chiapas, México. IBCiencias, 7(1), 1-7.

Grenda, T., Grabczak, M., Goldsztejn, M., Kozieł, N., Kwiatek, K., Pohorecka, K., ... Bober, A. (2018), Clostridium perfringens spores in Polish honey samples. Journal of Veterinary Science, 62(3), 281284. DOl: 10.2478/jvetres-2018-0040

Grenda, T., Grabczak, M., Sieradzki, Z., Kwiatek, K., Pohorecka, K., Skubida, M., Bober, A. (2018). Clostridium botulinum spores in Polish honey samples. Journal of Veterinary Science, 19(5), 635642. DOI: 10.4142/jvs.2018.19.5.635

Guadalix, M., Lorenzo, C. de, González, M., Navarro, T., Iglesias, T., Pérez, R. A., Sanz, J. (2002). La miel de Madrid. Consejería de Economía e Innovación Tecnológica, Madrid, España.

Gutiérrez, M.G., Enriquez, E., Lusco, L., Rodríguez M.A., Persano, O.L., Vit, P. (2009). Characterization of Melipona beecheil and Melipona solani honey from Guatemala. Revista de la Facultad de Farmacia, 50(1), 2-6.

Huidobro, J.F., \& Simal, L.J. (1984). Parámetros de calidad de la miel $V$. Índice de diastasas. OFFARM, 3(11), 705-713.

ICMSF (2001). Microorganismos de los alimentos 6: Ecología microbiana de los productos alimentarios. International Commission on Microbiological Specifications for Foods. Editorial Acribia: Zaragoza.

Kačániová, M., Melich, M., Kňazovická, V., Haščík, P., Sudzinová, J., Pavličová, S., Čuboň, J. (2009). The indicator microorganisms value in relation to primary contamination of honey. Zootehnie și Biotehnologii, 42(2), 159-166.

Karabagias, I.K., Badeka, A., Kontakos, S., Kontominas, M.G. (2014). Characterization and classi fi cation of Thymus capitatus (L.) honey according to geographical origin based on volatile compounds, physicochemical parameters and chemometrics. Food Research International, 55, 363-372. DOl: 10.1016/j.foodres.2013.11.032
Lage, L.G.A., Coelho, L.L., Resende, H.C., Tavares, M.G., Campos, L.A.O., Fernandes-Salomão, T.M. (2012). Honey physicochemical properties of three species of the Brazilian Melipona. Anais da Academia Brasileira de Ciências, 84(3), 605-608. D0l: 10.1590/ S0001-37652012005000051.

Leonhardt, S.D., \& Kaltenpoth, M. (2014). Microbial communities of three sympatric Australian stingless bee species. PLOS ONE, 9(8), 1-6. DOl: 10.1371/ journal.pone.0105718

Malaysian Standard (2017). Kelulut (Stingless Bee) Honey- Specification: MS 2683:2017, Department of Standards Malaysia.

Mendes da Escóssia, P.C., Rociene, A.M.C., Siveira, S.O. Oliveira, J.C., Alves da Silva, J.B. (2018). Microbiological quality of honey from stingless bee, jandaíra (Melipona subnitida), from the semiarid region of Brazil. Ciência Rural, 48(9), 1-6. DOl: 10.1590/01038478cr20180151

Menezes, C., Vollet, N.A., Contrera, F.A.F.L., Venturieri, G.C., Imperatriz, F.V.L. (2013). The role of useful microorganisms to stingless bee and stingless beekeeping. In: Pot-Honey. Vit, P., Pedro, S., Roubik, D. Eds. Springer, New York, NY. pp. 153 - 170.

Michener, C.D. (2007). The bees of the world. John Hopkins University Press: Baltimore.

Ministry of Health in Peru. Ministerio de Salud del Perú. Norma sanitaria que establece los criterios microbiológicos de calidad sanitaria e inocuidad para los alimentos y bebidas de consumo humano. Resolución Ministerial 591-2008. Lima, Perú, Diario Oficial El Peruano. 27 ago. 25 p.

Moguel, O.Y., Echazarreta, G.C., Mora, E.R. (2005). Calidad fisicoquímica de la miel de abeja Apis mellifera producida en el estado de Yucatán durante diferentes etapas del proceso de producción y tipos de floración. Técnica Pecuaria en México, 43(3), 323334. DOl: 10.22319/rmcp.v43i3.1369

Moo, H.V.M., González, A.G.A., Lira, M.J. D., Pérez, P.E. (2015). Physicochemical properties of Melipona 
beecheil honey of the Yucatan Peninsula. Journal of Food Research, 4(5), 24-32. DOl: 10.5539/jfr.l $\mathrm{v} 4 \cap 5 \mathrm{p} 24$

Moragas, M., Valcárcel, S., Chirapuzu, A., Pablo de, B. (2019). Recopilación de normas microbiológicas de los alimentos y asimilados (superficies, aguas diferentes de consumo, subproductos) y otros parámetros físico-químicos de interés sanitario. Boletín Oficial del País Vasco.

Mossel, D.A.A., Moreno, B., Struijk, C.B. (2003). Microbiología de los alimentos. 2. Ed. Editorial Acribia: Zaragoza.

NMX, (2006). NMX-F-036-NORMEX-2006. Alimentos-Miel-Especificaciones y métodos de prueba. 24 de enero del 2007. Diario Oficial de la Federación.

NOM, (2018). NOM-004-SAG/GAN-2018, Producción de miel y especificaciones. 14 de febrero del 2020. Diario Oficial de la Federación.

Nordin, A., Sainik, N.Q.A.V., Chowdhury, S.R., Saim, B.A., Idrus, R.B.H. (2018). Physicochemical properties of stingless bee honey from around the globe: A comprehensive review. Journal of Food Composition and Analysis, 73, 91-102. DOl: 10.1016/j. jfca.2018.06.002

Nunes, S.P., Piot, N., Meeus, I., Blochtein, B., Smagghe, G. (2016). Absence of Leishmaniinae and Nosematidae in stingless bee. Scientific Reports, 6, 32547. DOl: 10.1038/srep32547

Official Gazette of the Republic of Argentina. Secretaría de Regulación y Gestión Sanitaria y Secretaría de Alimentos y Bioeconomía Resolución Conjunta 17/2019. RESFC-2019-17-APNSRYGS\#MSYDS. Boletín Oficial de la República de Argentina.

Olaitan, P.B., Adeleke, O.E., Ola, I.O. (2007). Honey: A reservoir for microorganisms and an inhibitory agent for microbes. African Health Sciences, 73), 159-165.

Oldroyd, B.P., \& Aanen, D.K. (2015). Entomology: A bee farming a fungus. Current Biology, 25, R1072-R1074. DOl: 10.1016/j.cub.2015.09.062

Oliveira, R.G.De, Jain, S., Luna, A.C., Freitas, S. (2017). Screening for quality indicators and phenolic compounds of biotechnological interest in honey samples from six species of stingless bee (Hymenoptera: Apidae). Journal of Food Science and Technology, 374), 552-557. DOl: 10.1590/1678$457 \times .25716$

Oliveira, R.M.A.,Viana, J.L., Sousa, H.A.C., Waldschmidt, A.M. (2018). Physico-chemical parameters of honey from Melipona mondury Smith, 1863 (Hymenoptera: Apidae: Meliponini). Journal of Agricultural Science, 10 (7), 196-205. DOl: 10.5539/jas.v10n7p196

Pajor, M., Worobo, R.W., Milewski, S., Szweda, P. (2018). The antimicrobial potential of bacteria isolated from honey samples produced in the apiaries located in Pomeranian Voivodeship in Northern Poland. International Journal of Environmental Research and Public Health, 15(9), 1-14. DOl: 10.3390/ ijerph15092002

Pasias, I.N., Kiriakou, I.K., Proestos, C. (2017). HMF and diastase activity in honeys: A fully validated approach and a chemometric analysis for identification of honey freshness and adulteration. Food Chemistry, 229,425-431.DOl: 10.1016/j.foodchem.2017.02.084

Pat, F.L.A., Anguebes, F.F., Pat, F..M.M., Henández, B.P., Ramos, R.R. (2018). Condición y perspectivas de la meliponicultura en comunidades mayas de la reserva de la biósfera Los Petenes, Campeche. Estudios de la Cultura Maya, 52, 227-254. DOl: 10.19130/iifl. ecm.2018.52.939

Ramón, S.J.M., Ruiz, R.J.C., Ortiz, V.E.L. (2015). Electrophoresis characterisation of protein as a method to establish the entomological origin of stingless bee honeys. Food Chemistry, 183, 43-48. DOl: 10.1016/j.foodchem.2015.03.015

Rao, P.V., Krishnan, K.T., Salleh, N., Gan, S.H. (2016). Biological and therapeutic effects of honey produced by honey bees and stingless bee: a comparative review. Revista Brasileira de Farmacognosia, 26(5), 
657-664. DOl: 10.1016/j.bjp.2016.01.012

Rosa, C.A., Lachance, M.A., Silva, J.O.C., Teixeira, A.C.P., Marini, M.M., Antonini, Y., Martins, R.P. (2003). Yeast communities associated with stingless bee. FEMS Yeast Research, 4(3), 271-275. DOl: 10.1016/S15671356(03)00173-9

Różańska, H., \& Osek, J. (2016). Effect of storage on microbiological quality of honey. Bulletin of the Veterinary Institute in Pulawy, 56, 12-15. DOl: 10.2478/v10213-012-0029-x

Salamanca, G.G., Henao, R.C., Moreno, G., Luna, A. (2000). Características microbiológicas de las mieles tropicales de Apis mellifera. Apiservices. Retrieved April 12, 2019, https://www.apiservices. biz/es/articulos/ordenar-por-popularidad/725caracteristicas-microbiologicas-mieles-tropicales

Salgado, S.M., Rabadzhiev, Y., Renon, E.M., lliev, I., Ivanova, I., Cristiano, S.W. (2017). Microorganisms in Honey. In Honey Analysis. (pp. 233-258). IntechOpen. DOl: 10.5772/67262.

Silva, T.M.S., Santos, F.P., Evangelista, R.A., Silva, E.M.S., Silva, G.S., Novais, J.S., ... Camara, C.A. (2013). Phenolic compounds, melissopalynological, physicochemical analysis and antioxidant activity of jandaíra (Melipona subnitida) honey. Journal of Food Composition and Analysis, 29, 10-18. D0l: 10.1016/j. jfca.2012.08.010.

Solayman, M., Islam, M.A., Paul, S., Ali, Y., Khalil, M.I, Alam, N., Gan, S.H. (2016). Physicochemical properties, minerals, trace elements, and heavy metals in honey of different origins: A comprehensive review. Comprehensive Reviews in Food Science and Food Safety, 15(1), 219-233. DOl: 10.1111/15414337.12182

Sousa, B.M.J., Leite, E., Souza, D., Marques, G., Magnani, M. (2016). Sugar profile, physicochemical and sensory aspects of mono floral honeys produced by different stingless bee species in Brazilian semiarid region. LWT - Food Science and Technology, 65, 645-651. DOl: doi.org/10.1016/j.Iwt.2015.08.058
Souza, B. de A., Carvalho, C.A.L. de, Sodré, G. da S., Marchini, L. C. (2004). Características físicoquímicas de amostras de mel de Melipona asilvai (Hymenoptera: Apidae). Ciência. Rural, 34(5), 16231624. DOl: 10.1590/s0103-84782004000500048

Souza, B., Roubik, D., Barth, O., Heard, T., Enríquez, E., Carvalho, C., Vit, P. (2006). Composition of stingless bee honey: Setting quality standards. Interciencia, $37(12), 867-875$.

Teixeira, A.C.P., Marini, M.M., Nicoli, J.R., Antonini, Y., Martins, R.P." Lachance, M.A., Rosa, C.A. (2003). Starmerella meliponinorum sp. nov." a novel Ascomycetous yeast species associated with stingless bee. International Journal of Systematic and Evolutionary Microbiology, 53(1), 339-343. DOl: 10.1099/ijs.0.02262-0

Terrab, A., Diez, M.J., Heredia, F.J. (2002). Characterisation of Moroccan unifloral honeys by their physicochemical characteristics. Food Chemistry, 79(3), 373-379. DOl: 10.1016/S03088146(02)00189-9

Tornuk, F., Karaman, S., Ozturk, I., Toker, O.S., Tastemur, B., Sagdic, O., Kayacier, A. (2013). Quality characterization of artisanal and retail Turkish blossom honeys: Determination of physicochemical, microbiological, bioactive properties and aroma profile. Industrial Crops and Products, 46, 124 -131. DOl: 10.1016/j.indcrop.2012.12.042

Torres, A., Garedew, A., Schmolz, E., Lamprecht, I. (2004). Calorimetric investigation of the antimicrobial action and insight into the chemical properties of "angelita" honey - a product of the stingless bee Tetragonisca angustula from Columbia. Thermochimica Acta, 415(1-2), 107-113. DOl: 10.1016/j.tca.2003.06.005

Vale, M.A., Gomes, F.A., Ferreira, J.B., Santos, B. (2018). Honey quality of Melipona sp. bees in Acre, Brazil. Acta Agronómica, 672), 201-207. DOl: 10.15446/ acag.v67n2.60836

Vázquez, Q.C.R., Moreno, T.R., Natividad, B.l, Quiñones, R.E. I., Vázquez S.C. (2018). Microbiological 
assessment of honey in Mexico. Revista Argentina de Microbiología. 50 (1), 75-80. DOl: 10.1016/j. ram.2017.04.005

Villanueva, G.R., Buchamann, S., Donovan, A.I., Roubik, D.W. (2005). Crianza y manejo de la abeja Xunan Kab en la Península de Yucatán. ECOSUR-CONABIO: Q. Roo, Méx.

Vit, P. (2008). Valorización de la miel de abejas sin aguijón (Meliponini). Revista de la Facultad de Farmacia, 50(2), 20-28.

Vit, P., Gonzalez, I., Sorroza, L., Pedro, S.R. (2016) Caracterización físicoquímica de miel de angelita Tetragonisca angustula (Latreille, 1811) producida en Esmeraldas. Ciencia Unemi, 9(20), 77-84. DOl: 10.29076/issn.2528-7737vol9iss20.2016pp77$84 p$

Vit, P., Medina, M., Enríquez M.E. (2004) Quality standards for medicinal uses of Meliponinae honey in Guatemala, Mexico and Venezuela. Bee World, 857, 2-5. DOl: 10.1080/0005772X.2004.11099603

Vit, P., Roubik, D., Barth, O., Heard, T., Enríquez, E." Carvalho, C., Bogdanov, S. (2006) Composición de la miel de abejas sin aguijón: estableciendo requisitos de calidad. Interciencia, 37(12), 867-875.
Vit, P., Vargas O., López, T., Maza, F. (2015). Meliponini biodiversity and medicinal uses of pot-honey from El Oro province in Ecuador. Emirates Journal of Food and Agriculture, 276), 502-506. DOl: 10.9755/ ejfa.2015.04.079

Yücel, Y., \& Sultanoglu, P. (2013). Characterization of honeys from Hatay region by their physicochemical properties combined with chemometrics. Food Bioscience, 1,16-25.DOl: 10.1016/j.fbio.2013.02.001

Zamora, L.G., \& Arias, M.L. (2011), Calidad microbiológica y actividad antimicrobiana de la miel de abejas sin aguijón. Revista Biomédica, 22(2), 5966. DOl: 10.32776/revbiomed.v22i2.101

Zandamela, M.E.M.F. (2008). Caracterización físico-química y evaluación sanitaria de la miel de Mozambique. Ph. D. Dissertation, Universidad de Barcelona. Barcelona, España. 